\title{
Decision Making Processes and Road Construction Projects Implementation in Rwanda. A Case of Zindiro- Birembo-Gasanze Road Construction Project in Gasabo District, Rwanda
}

\author{
KAYITESI Claire ${ }^{1}$ GITAHI Njenga ${ }^{2}$ \\ ${ }^{1}$ MBA Student, Mount Kenya University, Rwanda \\ ${ }^{2}$ Senior Lecturer, Mount Kenya University, Rwanda \\ DOI: 10.29322/IJSRP.11.11.2021.p11912 \\ http://dx.doi.org/10.29322/IJSRP.11.11.2021.p11912
}

\begin{abstract}
Rwanda is one of the African countries which are putting more energy to raise the economic developments of the country which require the creation and innovation of various activities in different sectors in the whole country including projects creation and their implementation processes. Projects face many challenges during their implementation process towards their objective success including failures due to poor plan; less decision-making process, poor procurements process, corruption and poor tendering and all these issues negatively impact the projects' success which as well impact the country economy. The purpose of the study was the investigation of decision-making impact on projects implementation in Rwanda taking the case zindiro-birembogasanze construction project implementation in Gasabo district.The researcher adopted the descriptive survey design and the study population comprised 647 respondents including 12 project managers, 30 district staff in charge of different project, 20 committee members and 18 committee chairpersons and 567 project beneficiaries. Findings indicated that implementation of roads construction project and Decision making process were correlative with the success of roads construction activities rate. The correlation coefficients are shown $\mathrm{r}=0.955$ is accordingly and was produced with $\mathrm{p}$-value of 000 of a 2-tailed. The findings show strong positive and statistically significant and the Decision-making process can be enhanced with the improved implementation of roads construction project significantly. The results revealed that the decision making process must be coherent with construction activities for early implementation of roads construction project as shown with the regression analysis $\mathrm{R}$ square of 0.912 indicating that decision making process are needed to implement and complete all activities of zindiro-birembo-gasanze roads constructions project in Gasabo district. Researcher recommended to the government to establish the policy on decision making strategies for public and private institution to ensure that there is successful and similar decision making processes used to promote all projects implementation and accomplishments, the ministry of infrastructure should establish clear and proper measures to the use of resources management to enhance good service delivery in the construction area.
\end{abstract}

Key words: Decision Making Processes, Roads, Project Implementation, Road Construction Projects, Zindiro-Birembo-Gasanze Construction Project.

\section{Introduction}

Decision making has been considered as positive contribution to the organization' functioning with minimum cost while getting all the needs choosing the least price but which is constructive. Still, these processes face certain difficulties (Millet,2011). Among these challenges are identified as the risk of stopping activities of provision, environmental changes, the state of products, the force that the organizer is endowed with but because the decision making and leadership are tremendously growing, there are a lot of strategies to be used to implement in order to combat for project implementation (Jeeva, 2018).

In Africa, efficient decision making is considered by public and private institutions as an addition to the strategies of managing project and the way of performing projects towards their performance Farrington (2010) details interests behind: money valorization, 
environmental conservation, exploitation of resources to the maximum, social affiliation increase, trust building in trade, new ideas and inventions, accurate behavior in case of failure so as to overcome and get situation restored, lowest cost, globalization and openness giving right to all to compete. Policies and leadership and decision making are critical for good project management and effective project implementation (Mantel, 2012).

In many African countries, leadership and decision making rely on part of spending money, elaboration of excellently communication and communication not only for public governance but also for growing private institutions. This view is supported by Oladipo (2008), in studying government projects in Nigeria he discovered failure in elaboration, practical weakness, little finance, unable personnel, insufficient monitoring and inadequate quality. Transaction cost theory explains the decision making and project leadership and controls managed by laws and regulations consisting of specified activities. These costs can be defined as administrative costs connected with the procurement procedures and controls. Soudry (2010) stated that an invented theory founded on agency where he identifies authoritative delegation in which a superior gives power to the subordinates so as for that one to make some decisions and then the operations run smoothly (Soudry,2010).

The theory creates a relationship in project administration is necessary and very important to the governmental and private functioning because that is where the major expenses go through the project performance in area of construction. It is concerned then with the reception of items, operations of service delivery and labor which consumes the government treasure (World Bank, 2015). As an example, fixed assets, rising of buildings and other infrastructure, keeping cleanliness, transportation of people and materials with expert payment and working with different project. Throughout the world, debates are varied and many people are attentive to the project and it brings to different restructuring activities both in the developed countries as well as in third world countries have developed reforms and regulations about buying and spending money with different project administration. Still the biggest trouble is, there is no identification of complete resolution. Telgen (2007) said that lack of complete regulations affects both the poor countries and the developed ones.

Hui, et al., (2011) analyzed project implementation in Malaysia and proclaimed that persons in charge were accused of violating prescribed descriptions, procedures and rules. Citing Gelderman, et al., (2006) suggests the following of demanded activities without emotional respect to the big personalities. Indeed, the observed result, In the past to comply was thought as assuming what says the legislation and ruling decrees (Snell, 2004).

In delivering service in the countries under development it is noticed that leadership and decision making is crucial (Basheka\& Bisangabasaija, 2010), as it consumes the less amount from complete expenditure. As an example it takes sixty per cent in Kenya governments and private encourage the different measures of project administration (Akech, 2005), fifty eight in Angola, forty in Malawi and seventy in Rwanda( Basheka,2016). In addition, these countries' decision making, and project administration procedures are influenced by international requirements (Akech, 2005),. In Rwanda, The act governing project administration is amended so as to comply with the requirements at the international qualification to manage different project Because the countries in the development need project support in their budget and how to make function of operations, then they must accomplish the required guidelines (Baily, 2015).

This case occurred to Rwanda because there had been the decentralization of the right to examine the service needs and conditions and project success and their implementation Being in respect with the Paris Declaration's pledges. It was necessary to make these changes and show the donors the transparency (Alexis, 2013). The transparency International Rwanda has researched and wrote a 2006 declaration that the process of buying goods took a half of the sum total of national budget. Typically, the calculations found 
decision making have impact of $13 \%$ of gross domestic product (GDP) and $40 \%$ of public expense in implementation of project(Alexis, 2013).

Building effective teams and decision making is not limited to a specific organization in their project implementation they need the good serve deliver and decision making for their project success; this is an approach that can be used anywhere that collaboration is required among multiple people, teams or projects. Every team needs very compact decision-making strategies to achieve the detailed goal in order to be successful. Due to ever-growing economic, political, and technological forces, more and more organizations are struggling to how effectively compete and become successful in today's constraints of scarce resources. They are often forced to work smarter, more strategically, and with better efficiency just to survive (Wageman, 2007).

The concepts of decision making appeared in the periods of industrial revolution where all institutions decided to move from hierarchical methods to the scientific methods of management to create productive companies and jobs creation in all areas of the institutions (Smith, 2013). The role of decision making in an institution has been accepted in many businesses due its impact on the organization performance as well as achieving its objectives smoothly (Alexis, 2013).Business owners, project managers and chief executive officers of global companies admired the ideas of using decision making to attain the organization purpose and to move from one level to higher level of success and this increased, facilitated their companies to attain success (Smith, 2013).

Three essential baselines to ensure effectiveness of project management which are timing, scope and price estimation are moderators that balance the state at which the performance has succeeded or failed. Decision making is one of the tools that drive the essential baselines of the projects, and these three essential baselines work hand in hand for the project success (Brown and Hyer (2010).

Sustainable construction is one of many subsets of sustainable development and refers to the creation of construction maintenance, operation of infrastructures, buildings and roads which help to shape communities in a way that sustains the environment, brings into existence long term durability and overall, enhances the quality of life (Winter, 2008). Envision sustainability rating system was used to identify and collect primary data, defining road sustainable construction in the context of current Rwandex - Remera road upgrading situation, identifying main stakeholders and tracking their influence for sustainable construction showed that there are many roads construction projects that meet many challenges such as failure due to improper decision making process, poor planning, less commitment of the team during project implementation, negligence of project management procedures during implementation and improper resources management and allocation(Nkurunziza \& Faraja,2019)

Road transport sector in Rwanda is promoted through roads construction in all districts however once you make a tour on the roads constructed in Gasabo district you encounter different areas where roads and bridges are smaller than others in same district, some not in good condition in different villages in the same district, lack of water canalization, for example the road of Zindiro-BiremboGasanze in the villages of Gasabo district is not built as roads of Kimironko-Gishushu-Nyarutarama roads and Kimironko- KibagagaNyarutarama-Giasozi yet they are in the same Gasabo district and all these were monitored by same construction agency. The construction of feeder roads in Rwanda are rapidly deteriorating which affect financial, Technical, vehicle operation cost increases and travel time also increase. For instance, the Zindiro-Birembo-Gasanze feeder road of Rwanda has already deteriorated as of date and now needs rehabilitation (Shyirambere, 2020). With those challenges, the researcher decided to assess the impact of decisionmaking process on roads construction projects implementation in Rwanda, a case of zindiro-birembo gasanze roads construction projects to enhance and promote the social economic development in the district and the transport services in general.

The main purpose of this research was to assess the impact of decision making process on road construction projects implementation in Rwanda, a case of Zindiro-Birembo-Basanze road construction project and also this paper were guided with the following specific objectives; 
i. To assess the decision-making process applied to Zindiro-Birembo-Gasanze construction project in Gasabo District, Rwanda.

ii. To determine the quality of roads construction projects implementation of Zindiro-Birembo-Gasanze construction project in Gasabo District

iii. To establish relationship between decisions making process and road construction projects implementation at ZindiroBirembo-Gasanze

\section{LITERATURE REVIEW}

\section{1 THEORITICAL LITERATURE}

\subsubsection{Project Decision making processes.}

The decision making is defined as the ways of using alternative possible choices to achieve the main goals of an institution and decision made lead on organization to the best possible results towards the organizational or personal objectives (Beaker, 2013).The decision making is the main step in the organization management and are made for solving, attempting all challenges, handle all issues and orient with the alternative solutions within all institution struggles that are not possible to avoided (Harrison, 2011).

There are many steps to follow for decision making where it begins from the identification of the problems, discovery or the findings, matching up with alternatives possible ways and select what to be done with the use of many courses of actions to solve totally the problems or it is like the ways of using different possible and available choices and choose the best one to slow down the issues within an organization (Terry, 2009).

\subsubsection{The factors influencing the Decision making in organization.}

Business competitors, client opportunity, integration of technology in business and the many ways of economic increase, it is better to focus on those factors today to enhance the decision making process in the institution ( Pielow,2010) and essentials steps for better decision making in an organization are the path from the identification and clarification of the problem, data collection with respect of all corners of problem identified, develop more strategies to solve the problems, selections of best available choice of course of actions to be undertaken, planning and executing the actions (Pielow,2010) Therefore all managers, organization managements and administration should respect those steps to make their institution more productive and performing the organizational objectives.

\subsubsection{Decision making process towards Project's implementation.}

The effect of decision making on the project's performance was raised in the studies done academically in the previous years (Jones et., 2018) and all academicians indicated that the decision making is a process made to deliberate particular options to attain main projects purpose and targeting the success compared with other projects, more factors are encouraged to relate the decision making process and the projects' success (Adeleke, 2018).

Many studies revealed that the decision making is made effectively to improve the organization performance if the organization meet new situation and the decision making is considered as the key elements to be used to achieve the organization and meet its success within the course of action undertaken (Jones et al.,2011) Therefore decision making had became an useful tool in many working areas and surely affect effectively the organizational structure and facilitate the human resource to develop their mindset , to motivate them for better projects implementation towards their better success (Adeleke,2018).

Kreitner (2012) stated that the decision making is the ways of identification and section of various tasks in the process of choosing best possible available option to resolve the problems raised in an institution. The process of activity selection implicate that the decision made should be weighed and weeded out, it indicate that decision making address an objective, mission and vision to be achieved and attained in an organization (Rogers,2001). 
Many companies managements meet many challenges to address their mission, goals and objectives, those challenges are mostly based on institution marketing system, its operational activities and all issues must be solved through significant decision making process with the respect of the organization target (Peter,2015) hence, the organization staff must be careful before deciding on the problem appeared to be sure if the decision made is not a cause of another problems to be solved means that essentials steps for better decision making in an organization are the path from the identification and clarification of the problem, data collection with respect of all corners of problem identified, develop more strategies to solve the problems, selections of best available choice of course of actions to be undertaken, planning and executing the actions (Pielow,2010).

The projects implementation in an organization require more details including decision making process as one of the ways of projects success and all steps of decision making must be respected to avoid more time used in the process of implementation, this means that any decision made to comply with organization problems in the business background , the whole process require more time and facilitate the management team to perform better within the organization ( Peter,2015).

\subsection{Empirical Literature}

\subsubsection{Decision making process in the Construction Projects implementation}

The construction projects performance are based on the measures taken by the staff members, the studies done on implementation of construction projects and the construction projects succeeds poorly due to the ineffective selection of procurement strategy and contribute to the failure the projects implementation (Dissanayak,2014). Reichet and lyneis,2013) stated that there are 3 measures structured to design a compact projects success which are the activity performance design, activity impact from the production and quality of the activity, impact from the top stream phase to low stream phase. According to Thomas (2012) argued that the best success factors for construction projects are creation of stable finance, dressing the work flow from the decision making, quality standardization, human safety and health, relate resources materials with projects beneficiaries, projects expert, managements team , claim and contract arguments. Projects periods is another factor that contribute in the implementation of building projects and the time is taken as the vital benchmarking for the evaluating the projects' success and their performance the organization projects (Chan, 2012).

There are keys elements which promote the projects' success such as quality, time, safety and health, cost, population, customers satisfaction and good communication(Cheung et al.,2014) and controlling strategy also is maintained as important factors identified to impact the construction projects implementation where a very projects mission, one or more projects success factors is required for implementing and achieving the projects goals ,objectives with the use of those keys elements (Navon,2015).

Human factors have a big impact in the clarification of construction projects success and determines its clear effect on human life and affect socially and economically the country developments (Pheng and Chuan, 2016). Ugwi and haupt (2017) stated that both early contractor involvement (ECI) and early supplier involvement (ESI) should reduce constructability related to the issues of projects performance like money related with delays, claims, wastage and rework.

The most managing team related to the practical activity on the field are correlated with projects scope and make the focus on the quality of contract drafted, quality of feedback to acquire the alternatives and make all acceptable changes to the contract and it was recommended for the foreign companies to evolve some practical projects managements skills indicated to facilitate the construction projects for better success (Ling et al., 2017).

\subsubsection{Challenges of Construction projects implementation}

Many research tried to indicate the reason that are based to set all construction projects behind the organized timeframe and the impact of the decision making for instance the delayed construction projects in the united states (Baldawin,2012) and Sullivan 2012 
assessed the delay causes in the big building projects in the united kingdom. Kaming et al., (2007) investigated the causes of time and high cost in building projects in Indonesia and the delay causes raised in Jordan by Odeh and Battaineh (2012).

The main challenges for building projects implementation are redesign of the contracts, low labor productivity competitiveness and poor plan and activity controlling and also the activity delays can be made by the projects owners, decision maker for the projects , miscommunication between contractors however more research targeted mostly on the clarification of cause of delay the building phase, make emphasis on the planned and executing activity and the decision making process for the project implementation(Dvir,2011).

According to the McManus et al.,2016 stated that many projects delays causes in architecture building projects and he argued that many projects faces the delay in the beginning phase of practical activity means that delays begin in the design phase with the ineffective project management and controlling, unavailability of the contactors to revise the implementation plan , uncontrolled time schedule ,less capability of the projects owners, less use of technology and its involvement the building activity, mismanagement ,uncoordinated system and exclusion of projects beneficiaries.

Toor and Ogumlana (2018) stated that the main challenges for construction projects in Thailand are related with country development where the infrastructure sectors faces the lack of infrastructure materials and incompetent labor market for resources ,inadequacy for contractors and customers, incompetency of consultants however they recommended that the government of Thailand would put in place the strong measures regarding how the training, good and sustainable resource be provided, building capacity in the construction sector to have the very high competent projects manager, integrate very high technology in the construction sector an create a strong and sustainable projects management strategy.

Chan and Kumaraswamy (2018) carried out the research to assess the keys elements contributing the projects delays in Hong Kong buildings projects and they found that there are a lot of cause for delays for buildings activities like the decision making process follow up and plan, administration system and execute of construction projects and class of building projects to be implemented in the country, last the capacity of the owner of the projects and contractors.

\subsubsection{Factors to be consideration for construction projects success}

There are many factors to be taken into accounts and that can affect positively the constructions projects performance and those factors are maintained as pivot of the constructions projects performance and also help the projects managers and implementers to enhance the opportunity to get more planned (Dvir, 2018).A set of determined criteria shown more chance to succeed or to fail the projects in an organizations and the big factors to be considered is the time to be taken for construction projects implementation for more outcomes (Westerved,2013).

The target of projects management is to assess or to identify the important keys elements that impacts the projects for success and implementations for desired outcomes from the projects works and deferent's studies indicated more about the real factors to succeed that the projects should depend on (Savolainien, 2012). There are more challenges faced in the identification of factors for succeeding projects, many studies put more efforts on the approaches to be used for implementation of successful projects in dynamical global market for the purpose of affecting the business changes in the world where all projects managers are encouraged to create and innovate more opportunity to attain the projects advantages competitively (Borza, 2014). The research made by the Popa, (2014) stated the management's process targeted to achieve the project's success to meet all desired outcome with the use of different success full factors and it helps the stakeholders to think more about their projects performance and implementation within projects operation due to the how the projects are planned ,the top managements support, projects schedule, customers consultants, man powers and 
human resources, technical tasks to be operated, customers consideration, monitoring and evaluation to get more feedback for projects activities (Davis,2014).

\subsubsection{Constructions projects implementation in Rwanda}

The keys factors for development sustainability is the creation and innovative building projects to promote the economic developments through infrastructure and technology developments, the infrastructure developed in the construction of roads to facilitate transport service ,bridges and other related building facility to enhance the sustainable developments of the society , also those projects based on infrastructure refers to the environmental protection, shaping the community livelihood ,imitative for durable materials to promote the life quality condition of life (Winter,2009) and on other side ,The main important issues to human being in $21^{\text {st }}$ Century is capacity to be recon ciliated with the ecosystem for long social welfare through the construction projects facilities globally (Miller,2011).

The government of Rwanda initiated the construction projects through roads construction, bridge construction, education facility, health facility and they were oriented through vision 2020 with target of having technological advanced transport facility , effectiveness of the cost for building service and promotion of quality of services delivery with respect of environmental protection measures therefore the construction service was developed through the Rwanda transport policy drafted to improve the quality of infrastructures specifically roads and bridges and for the infrastructure sustainability developments in line with increase of national economic growth, human capacity building for product exchanges and service delivery nationally and regionally(Mininfra,2012).

The infrastructure development have the main purpose of creation and innovative methods to integrate the construction projects socially ,economically with durable materials ,viability of materials to enhance more buildings projects including the bridges constructions, roads constructions but there is a inadequacy of tangible strategies to give sustainable guarantee for assessing and analyzing during highways design for pavements, building and sustainability in Kigali city as long as the news roads build in Rwanda and the others in upgrading level to facilitate the lifecycle satisfaction of developments needs, to sustain the environment protection and the economic growth enhancement (Rema,2016).

Infrastructure sectors is the main services which provide more important contribution to economic growth of the country through the provision of health facility, education facility, transport facility but this service still having many challenges in Rwanda such as high cost related the construction materials, time frame and contractors mindset, lack of competent engineers where the country required to allow the foreign companies to intervene in the construction projects in Rwanda, wastage of materials and lack of training center based on construction activity only in Rwanda (RTDA,2016).

\subsection{Theoretical framework}

This part indicates how the research is related with the other studies made and also focus on the various theories that can facilitate this study to achieve its objectives therefore this research weas

supported with different theories like legitimacy theory and theory of agency.

\subsubsection{Theory of agency}

The agency theory has main focus on the creation of correlation of activity in the institution (Meckling ,2015) and is implicated in the organization where the authority allow to the subordinate to all participate in the organization activity (Eisenhardt,2009). The agency theory also limited on the benefit targeted by the managers wanted to obtain in organization and secondly it is based on how the leaders struggle with their profits and success of the organization (Xingxing,2012). Theory challenges appeared in case that the subordinate purpose is designed from the leaders and investigating if the oriented workers make what is expected to be a problem. It is also complicated to supervise a very worker in to see whether all task delegated are done timely in an organization. With the regards of this study, it is mainly focus on the decision marking for project implementation in the company therefore this theory help the 
ISSN 2250-3153

authority to share all challenges happen in their organization during projects implementation for its success to avoid the projects failure and create proper management strategy to the projects implementation. This theory is used in buying, selling and the correlation may happen when challenges appeared during the buying process which need more than needed to mention the comparison (Xingxing,2012).

\subsubsection{Legitimacy theory}

It is based on how the authorities of public boards and enteritis allocate their activities to the key personnel towards the profits of the community (Wilmshurts \& frost, 2000).The legitimacy theories make a limitation on the applicable works ,appropriateness and visible in all process towards the profits of the community with respect of the norms, rules, values and social believes (Suchman,2007). Due to the statement above and with regards of the main purpose of this study in the line with the success of the projects, public entities can face many challenges due to the failure of the projects caused by different issues like corruptions, decision making process mismanagements from unqualified workers, less technology involvements or less motivation to key actors of the projects implementation, this has have relationship with the projects where they face different issues also like cronyism and nepotism which could impact the management strategies for instance zindiro-birembo gasanze construction projects in Gasabo district, Rwanda. This research used the legitimacy theory to assess if the projects managers maintain all sources of risks for proper managements measures with the target of good performance in the public institution as well as private and the society benefits.

\subsection{Conceptual framework}

The conceptual framework figure below explains the relationship between the variables under the study, Decision making process (Independent Variable) and Roads Construction Project implementation (Dependent variable).

Independent variables

\section{Decision making process}

Do follow up on projects activities, Feedback and action done Time/schedule

$>$ Respect of rules and regulation for roads construction

Alternative approaches to solve problem and choose the best possible option

\section{Dependent variable}

\section{Roads Construction Project implementation}

- Good use of available resources

- Timely Project success

- Effective work and reduced cost

\section{In_rvening variables}

- Dynamic technology for civil engineering

- Governmental policy regarding infrastructure

- Natural Climate change 
The figure 1 indicates relationship between decision making and construction project implementation and their operational meaning to achieve the present goals of the research. In this section, we outlined the relationship between independents variable and independent variables their influence on research areas and in whole country.

\section{RESEARCH METHODOLOGY}

\subsection{Research Design and Population}

The Research design was descriptive, and it was based on the identification of different attitude, ideas, constructive comments and more opinions related with the research objectives (Poronsky, 2009). The descriptive survey design was chosen for this study because this research seeks to gain the real observable facts, put many perceptions into the phenomena to provide the basic information in the areas under investigation, this design also is based on how the situation or on what situation presents and its relationship between the previous moment that impacted the presents condition in a study area. Therefore, descriptive survey design adapted the quantitative and qualitative research approaches, impact and relationship was measured by the inferential statistics based on progressive inquiry concerning the role of decision making on construction project implementation in Rwanda specifically zindiro-birembo-gasanze construction project in Gasabo district.

According to Grove, (1993) stated that targeted population as a collection of personalities which are eligible to participate in the enquiry (Grove,1993). The participants were 647 respondents including 12 project managers, 30 district staff in charge of different project, 20 committee members and 18 committee chairpersons and 567 project beneficiaries and all above participants was taken with the respect of research purpose.

\subsection{Sample Design}

Researcher used simple random sampling to select the project managers; simple random sampling was used to select RTDA staff in charge of projects and researcher used purposive sampling to select project beneficiaries. These sampling techniques were selected based on the experience, qualities, and awareness in all respondents to provide virtue information (Bernard, 2012). The choice of sample deserves attentive hints in withdrawing from entire group and to provide information that can scientifically be tested (Denscombe,2018). The number respondents was calculated by using the Yamane formula (2011). This formula involves in calculating the sample size from target population: when the population is 647 , the possible sample size is 247 respondents.

$$
n=\frac{N}{1+N(e) 2}
$$

Source: Yamane, 1970

$\mathbf{N}$ : stands for the target population

e: is the level of precision equals to (5\%)

n: Sample size

$$
n=\frac{647}{1+647(0.05)^{2}}=\frac{647}{1+647(0.0025)} \quad n=247
$$

Table 1Distribution of target population

\section{Group of respondents}

Targeted population

RTDA staff
Percentage (\%)

2.5

5
Sample size

11

This publication is licensed under Creative Commons Attribution CC BY. 
$\begin{array}{llll}\text { Project beneficiaries } & 567 & 87.5 & 219\end{array}$

$\begin{array}{llll}\text { committee member s } & 20 & 2.5 & 8\end{array}$

$\begin{array}{llll}\text { Chairperson } & 18 & 2.5 & 4\end{array}$

$\begin{array}{llll}\text { Total } & 647 & 100 & 247\end{array}$

Source: Researcher, 2021

\section{RESEARCH FINDINGS AND DISCUSSION}

\subsection{Introduction}

This chapter, indicate the analysis and interpretation of collected data from the field. In line with the set objectives of the study, the researcher described all findings based on each specific objective. Also, it included tables and figures representing the findings from the study that was conducted by using questionnaire and interviews from different respondents included in this study.

\subsection{Demographic characteristic of respondents}

\subsection{Category of respondents}

This part indicated the demographic characteristics of respondents; they were classified according to their age, level of education, gender and working experience while working on such projects. The total number of respondents for this case study was 247 which included 5project managers, 11 RTDA Staff project, 219 project beneficiaries, 4 chairpersons and 8commitee members. Researcher used questionnaire for RTDA staff, project beneficiaries and committee members, also researcher used the interview for the project chairpersons and project managers. The respondents were given the questionnaire to fill and the response rate was $100 \%$ as shown in table 2

\section{Table 4. 1Questionnaire turn rate}

\begin{tabular}{llcc}
\hline Statements & Frequency & Valid Percent \\
\hline \multirow{4}{*}{ Valid } & RTDA Staff & 11 & 4.6 \\
& Project beneficiaries & 219 & 92.0 \\
& committee members & 8 & 3.4 \\
& Total & $\mathbf{2 3 8}$ & $\mathbf{1 0 0 . 0}$ \\
\hline
\end{tabular}

Researcher, 2021

Table 2 indicates the returned questionnaire from respondents. it shown that $92.0 \%$ of all participants were project beneficiaries, $3.4 \%$ of respondents were committee members and $4.6 \%$ of distributed questionnaire were the RTDA staff participated in this study. The information provided by all respondents in questionnaire was used played a crucial role in this research.

\section{2 Gender of respondents}

Much as the researcher used random selection extra care had to be taken to ensure that all genders were represented to avoid any bias and establish fairness in answers provided and the results are shown in table 3

Table 3. Gender of respondents

\begin{tabular}{llcc}
\hline Statement & & Frequency & Valid Percent \\
\hline \multirow{3}{*}{ Valid } & Male & 126 & 52.9 \\
& Female & & \\
& Total & 112 & 47.1 \\
& & $\mathbf{2 3 8}$ & $\mathbf{1 0 0 . 0}$ \\
\hline
\end{tabular}

Researcher, 2021 
The findings revealed that $52.9 \%$ of the respondents were male and only $47.1 \%$ were female. The results are very typical since this is a technical field that requires a lot of manpower and this tends not to favor women due to the kind of tasks involved and all gender were included to ensure the equality in the response and the table 4 indicate the gender of interviewed respondents were also respected

Table 4 Gender of interviewed respondents

\begin{tabular}{llcc}
\hline Statement & & Frequency & Valid Percent \\
\hline \multirow{2}{*}{ Valid } & Male & 7 & 77.7 \\
& Female & 2 & 22.3 \\
& Total & $\mathbf{9}$ & $\mathbf{1 0 0 . 0}$ \\
\hline
\end{tabular}

Researcher, 2021

Findings reveled that during interview, gender were respected where $77.7 \%$ of respondents were male while $22.3 \%$ of all respondents were female

\subsubsection{Respondents educational level}

The researcher was interested to know the educational level of respondents. All qualifications were based on the field of specialization and these included Management, engineering and accounting, project management. Some respondents were qualified in technology management and these are the staff that was left behind to maintain the construction activity. The results were summarized in the table 5

\section{Table 5 Education level of respondents}

\begin{tabular}{llcc}
\hline Statement & & Frequency & Valid Percent \\
& & & \\
\hline \multirow{4}{*}{ Valid } & A' level & 19 & 8.0 \\
& Diploma & 120 & 50.4 \\
& Bachelor & 74 & 31.1 \\
& Masters & 25 & 10.5 \\
& Total & $\mathbf{2 3 8}$ & $\mathbf{1 0 0 . 0}$ \\
\hline
\end{tabular}

\section{Researcher, 2021}

The findings shown in table 5 indicated that the all respondents have a basic education to provide relevant information therefore the $50.4 \%$ of all respondents were qualified at diploma degree in technical education, $8.0 \%$ of all respondents had A 'level certificate , $31.1 \%$ of all respondents were at bachelor degree and lastly $10.5 \%$ of all respondents were on masters level Therefore, all respondents are fully qualified in the areas of technology and are able to provide all information related to the constructions project.

\subsubsection{Period of experience with construction activities}

Researcher wanted to find out the level of experience of the workers that were directly involved in construction activities and. The questions asked were to help establish the level of experience they have attained while working with such systems or on construction projects. The results were summarized in the table 6

Table 6 working experience of respondents

\begin{tabular}{llcc}
\hline Statements & Frequency & Valid Percent \\
\hline Valid & $0--3$ years & 63 & 26.5 \\
\hline
\end{tabular}




\begin{tabular}{lcc}
$4--7$ years & 34 & 14.3 \\
$8--13$ years & 113 & 47.5 \\
13years and above & 28 & 11.8 \\
Total & $\mathbf{2 3 8}$ & $\mathbf{1 0 0 . 0}$ \\
\hline
\end{tabular}

\section{Primary Data, 2021}

The results revealed in table 6 indicated that majority of respondents were familiar with the constructions activities and had experienced all issues related to the zindiro-birembo-gasanze road construction project where the $26.5 \%$ of all participants were in range of 1 year and 3years, $14.3 \%$ of all respondents were in the range of 4 and 7 years of working experiences in the field of constructions while $11.8 \%$ of the respondents were above 13 years of working experience with the constructions projects, with the results indicated in the table 4.5 majority of respondents have full information about the impact of decision making process on road construction project implementation in Rwanda, a case of zindiro-birembo-gasanze road construction project and also all respondents have raised that they know every issues done in constructions activities therefore they are experienced to ensure that all information provided play a big role in this study.

\subsection{Presentation of findings}

This research was focused on the assessment the impact of decision-making process on road construction project implementation in Rwanda, a case of zindiro-birembo-gasanze road construction project. The specific objectives of this study were the following: to assess the decision making process applied to zindiro-birembo-gasanze construction project in Gasabo District, to determine the level of roads construction projects implementation of zindiro-birembo-gasanze construction project in Gasabo district, to establish relationship between decisions making process and road construction projects implementation at zindiro-birembo-gasanze roads constructions. The findings indicated by the data collected from zindiro-birembo-gasanze roads constructions were discussed and presented with the respect to each of the specific objectives.

\subsubsection{Decision making process applied to zindiro-birembo-gasanze construction project}

The first objective of this study was to assess the decision making process applied to zindiro-birembo-gasanze construction project in Gasabo District. During data collections, the respondents were asked to show their views on different factors the decision making process applied to zindiro-birembo-gasanze construction project in Gasabo District. The results revealed were summarized in the table 


\section{Table 7.Decision making process}

\begin{tabular}{|c|c|c|c|c|c|c|c|c|c|c|}
\hline \multirow[b]{2}{*}{ Statements } & \multicolumn{2}{|l|}{ SD } & \multicolumn{2}{|c|}{$\mathbf{D}$} & \multicolumn{2}{|l|}{$\mathbf{N}$} & \multicolumn{2}{|l|}{$\mathbf{A}$} & \multicolumn{2}{|l|}{$\mathbf{S A}$} \\
\hline & $\mathbf{F r}$ & $\%$ & $\mathbf{F r}$ & $\%$ & $\mathbf{F r}$ & $\%$ & $\mathbf{F r}$ & $\%$ & $\mathbf{F r}$ & $\%$ \\
\hline $\begin{array}{l}\text { The clarification of the problem is considered be } \\
\text { taking decision in your project }\end{array}$ & 1 & 0.4 & 10 & 4.2 & 3 & 1.3 & 78 & 32.8 & 146 & 61.3 \\
\hline $\begin{array}{l}\text { Analyzing different alternatives solution and } \\
\text { selection of the best solution is one of decision } \\
\text { making process used by initiating roads }\end{array}$ & & & & & & & & & & \\
\hline construction projects activities. & 7 & 2.9 & 20 & 8.4 & 6 & 2.5 & 123 & 51.7 & 82 & 34.5 \\
\hline $\begin{array}{l}\text { Identification limiting factors is a decision making } \\
\text { process used by the projects manager during the } \\
\text { implementation of the road construction projects }\end{array}$ & 9 & 3.8 & 14 & 5.9 & 2 & 0.8 & 50 & 21.0 & 163 & 68.5 \\
\hline $\begin{array}{l}\text { Well Developed potential alternatives solution and } \\
\text { clear project targets are dressed to assure Progress }\end{array}$ & & & & & & & & & & \\
\hline and overcome obstacles to progress. & 8 & 3.4 & 8 & 3.4 & 9 & 3.8 & 82 & 34.5 & 131 & 55.0 \\
\hline $\begin{array}{l}\text { Good established implementation process is } \\
\text { respected before the ongoing of roads construction } \\
\text { projects implementation }\end{array}$ & 35 & 14.7 & 9 & 3.8 & 8 & 3.4 & 112 & 47.1 & 74 & 31.1 \\
\hline $\begin{array}{l}\text { Clear monitoring and evaluation system is } \\
\text { maintained as one of decision making process to } \\
\text { enhance to roads construction projects }\end{array}$ & & & & & & & & & & \\
\hline implementation & 3 & 1.3 & 8 & 3.4 & 10 & 4.2 & 122 & 51.3 & 95 & 39.9 \\
\hline
\end{tabular}

\section{Primary Data, 2021}

Results revealed in table 7 indicated different process applied in the constructions where the first process were based on how the problem is clarified considered be taking decision making in construction projects and those specifying issues done at zindirobirembo-gasanze construction projects the majority of respondents. The findings indicated in table 4.6 shown that the majority (94.1\%) of respondents were agreed that the problems clarified and raised in the project and are taken into consideration in the decision making process, $1.3 \%$ of the respondents were neutral to the statement where the respondents refused to show the views on the how the problems were clarified and their consideration in the zindiro-birembo-gasanze construction projects while the $4.6 \%$ of the respondents were disagree to the statements by indicating that all clarified issues are not noted in the decision making process therefore the findings highlights that all clarified problems are considered in the decision making process in zindiro-birembogasanze construction projects in Gasabo district.

The second statement indicated in the table 7 were how projects staff analysis different alternatives solution and selection of the best solution is one of decision making process used by initiating roads construction projects activities in zindiro-birembo-gasanze construction projects in Gasabo district, the findings indicated that the majority (86.2\%)of respondents were agreed with the 
statement by indicating that they maintain the process of analyzing different alternatives solution and selection of the best solution is one of decision making process used by initiating roads construction projects activities, also the $11.3 \%$ of respondents were disagreed with the statements where they indicated that they are not aware how the constructions projects staff take the best solutions on different issues raised in constructions activities while the $2.5 \%$ of respondents were neutral to the statement.

The third view from the respondents were based on identification of the limiting factors decision making used by project manager during the implementation of the road construction projects, the results indicated in table 7 revealed that majority (89.5\%) of respondents were aware on Identification limiting factors is a decision making process used by the projects manager during the implementation of the road construction projects, the $9.7 \%$ of respondents were disagreed with this statement while the $0.8 \%$ of respondent were neutral to the statement. The forth process was focused on how well developed potential alternatives solution and clear project targets are dressed to assure progress and overcome obstacles to progress, the results shown in table 7 that the majority (89.5\%)of respondents accepted that there are a well-developed potentials alternatives solutions and clear projects which are highly dressed to the projects performance and to reduce or eliminate more obstacles in the projects performance, $6.8 \%$ of respondents were disagreed that there is a well-developed potentials alternatives solutions and clear projects which are highly dressed to the projects performance while the $3.8 \%$ of respondents were refused to give any information about well-developed potential alternatives solution and clear project targets are dressed to assure Progress and overcome obstacles to progress.

The fifth statements were based on the good established implementation procedure is respected before the ongoing of roads construction projects implementation, the findings revealed that the majority (78.2\%) of respondents were agreed that there good established implementation process is respected before the ongoing of roads construction projects implementation and they appreciated how they have very clear project implementation process and the $18.5 \%$ of respondents were indicated that there is no clear established channel for project implementation while $3.4 \%$ of respondents were neutral to statement by indicating that there do know anything about the project implementation problems therefore the zindiro-birembo-gasanze construction projects has the clear established good project implementation.

The questions one were "How the Effective decision making processes is developed through shared experiences and practice" the answers " most of participants responded that they call upon all concerned people to develop the way of decision making process through shared experienced, competencies, skills, attitude, values knowledge and practice before taking decision for better roads constructions projects implementation, they take on different opportunities to the all concerned implementers to raise ideas for decision making process"

Question two for interviews were based on "What are the main of decision making process followed in the roads construction projects implementation in your districts?"

Answer were "they said that they use different decision-making process strategies like clarification of the problem, analyzing different alternatives solution and selection of the best solution, Identification limiting factors, well Developed potential alternatives solution and clear project targets, Clear monitoring and evaluation system and they confirmed that those strategies impacted positively the zindiro-birembo-gasanze roads construction projects implementation in Gasabo District, Rwanda ”

\subsubsection{Level of roads construction projects implementation}

The second objective of study were to determine the level of roads construction projects implementation in Gasabo District, the participants were asked to show their views by answering the questionnaires in the space provided and the results were interpreted in the form of 1= Disagree, 2=Neutral, 3=Agree, as Likert scale of 1-3. Responses were added and interpreted using means where 1.0- 
1.9 represented disagree and $2.0-2.9$ represented neither agree nor disagree, $3.0-3.9$ represented agree, and $4.0-5.0$ represented strongly agree. Results were as documented in Table 8

\section{Table 8Decision making process}

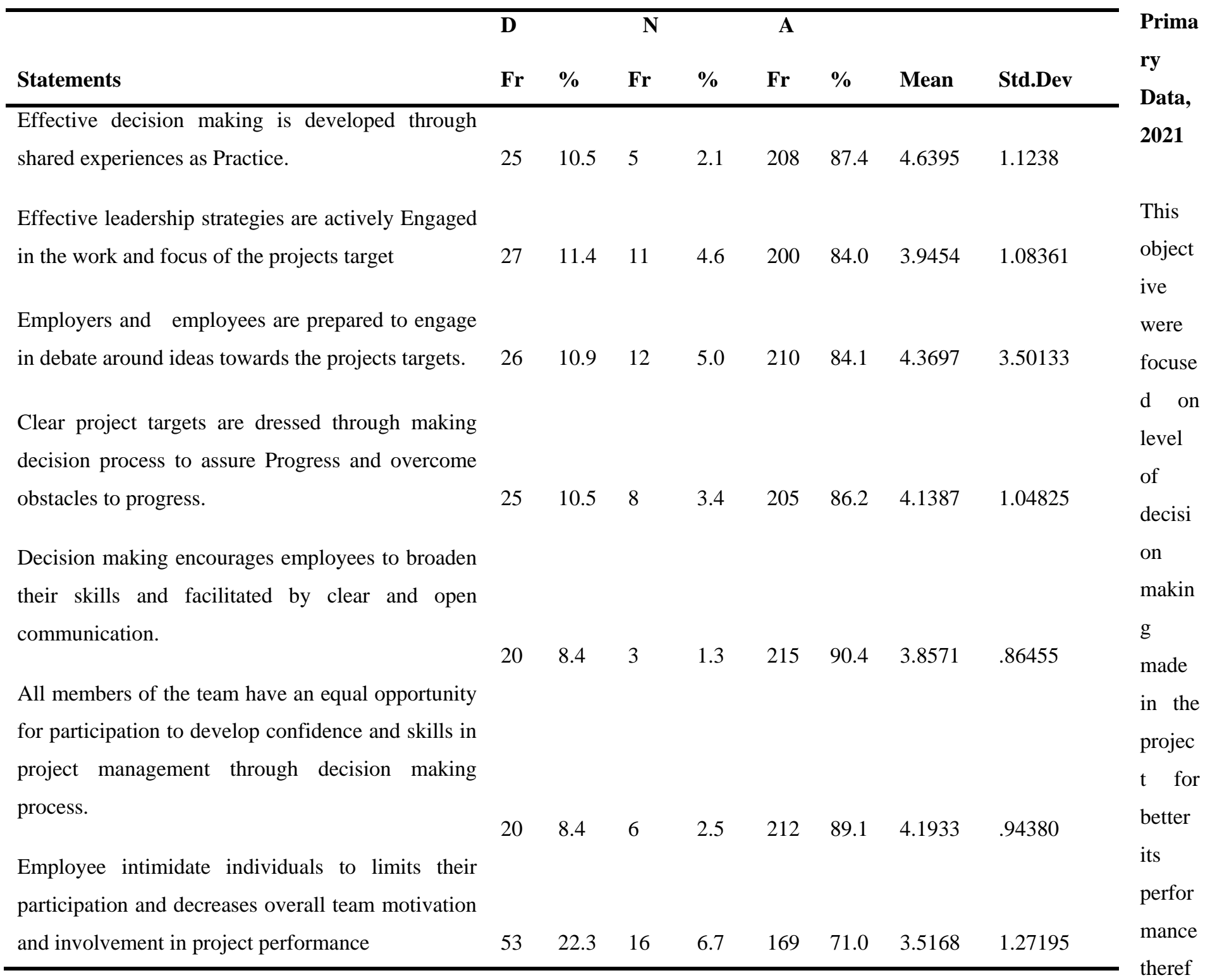

ore the first statement were based on the effective decision making is developed through shared experiences as Practice, the majority $(87.4 \%)$ of respondents were agreed that in the stated project there are the effective decision making process which are developed through shared experiences as Practice while the $10.5 \%$ of respondents disagreed the statement and $2.1 \%$ of respondents refused to say anything about the effectiveness of the decision making process which are developed through shared experiences as practice also the findings were confirmed by the means of 4.6395 which is very high to confirm that there is a very high level of the effective decision making process which are developed through shared experiences as practice

Secondly the findings revealed that the project staff struggle for a systematic leadership styles and researcher want to know how more effective leadership strategies are actively Engaged in the work and focus on zindiro-birembo-gasanze construction project in Gasabo District objectives , the findings were that the majority (84.0\%) of participants accepted that various and effective leadership This publication is licensed under Creative Commons Attribution CC BY. 
strategies are actively engaged in the projects with the main objective, the $11.4 \%$ of respondents disagreed with the statement means that they do not know about the leadership strategies used in the project implementation process while the $4.6 \%$ of respondents were neutral to the statements and also results are highlighted by the means of 3.9454 which is very high to confirm that there are more effective leadership strategies are used for the project objective as it is shown in the table 8

The results shown in the table 8 indicated that employers and employees are prepared to engage in debate around ideas towards the projects targets for better construction projects implementation, the majority $(84.1 \%)$ of respondents were agreed that all employers and employees are prepared to engage in debate around ideas towards the projects targets, $10.9 \%$ of participants disagreed that employers and employees are prepared to engage in debate around ideas towards the projects targets while the 5.0\% of respondents were neutral to the statements and it is confirmed with the means of 4.3697 which is very high to accept that the employer and employees are prepared to engage in debate around ideas towards the projects targets.

Other statement were based on how the project targets are dressed through making decision process to assure Progress and overcome obstacles to progress, the respondents were motivated to show their acceptance where the majority $(86.2 \%)$ of respondents were indicated that clear project targets are dressed through making decision process to assure Progress and overcome obstacles to progress and the $10.5 \%$ of the respondent disagreed that there is no clear project targets to be dressed through making decision process to assure Progress and overcome obstacles to progress while $3.4 \%$ of respondents were refused to indicated their views on this statement with the mean of 4.1387 which is very high to confirm that zindiro-birembo-gasanze construction project have the project targets which dressed through making decision process to assure Progress and overcome obstacles to progress

Researcher wanted to know different levels of construction projects implementation and indicated that he wanted to show if the decision making process made encourages employees to broaden their skills and facilitated by clear and open communication, where the majority (90.4\%) of respondents were agreed with the statement and $8.4 \%$ of respondents were disagreed with while $1.3 \%$ of them refused to say anything about how decision making encourages employees to broaden their skills and facilitated by clear and open communication and it is shown by the means of 3.8571 which is high to confirm that decision making encourages employees to broaden their skills and facilitated by clear and open communication in zindiro-birembo-gasanze roads construction project.

Other arguments discussed were based on how all members of the team have an equal opportunity for participation to develop confidence and skills in project management through decision making process and the findings revealed that the $89.1 \%$ of respondents mentioned that all members of the team have an equal opportunity for participation to develop confidence and skills in project management through decision making process and $8.4 \%$ of respondents were not aware with the statement while $2.5 \%$ of participants were neutral means they do not want to indicate their understanding about how all members of the team have an equal opportunity for participation to develop confidence and skills in project management through decision making process and they are shown by the means of 4.1933 .

The last ideas were based on how employee intimidate individuals to limits their participation and decreases overall team motivation and involvement in project performance, the findings shown in table 4.7 highlighted that employee intimidate individuals to limits their participation and decreases overall team motivation and involvement in project where the $71.0 \%$ of respondents were agreed with the statement while $22.3 \%$ of participants were disagreed that all employee intimidate individuals to limits their participation and decreases overall team motivation and involvement in project performance and $6.7 \%$ of respondents refused to be integrated in the discussion on the statement so it is confirmed with the mean of 3.5168 which is high to mean that Employee intimidate individuals to limits their participation and decreases overall team motivation and involvement in project performance. 
The interviews with project manager and chairman of the projects were asked about the decision making process applied to the zindiro-birembo-gasanze construction projects, the questions one on objective two focused on the impact of decision making strategies on the implementation of zindiro-birembo-gasanze roads construction projects in Gasabo district and the question were "How the decision making process made affect the road construction projects implementation in your district?" the answer were "all decision made in the implementation of zindiro-birembo-gasanze roads construction projects have the positive impact except certain obstacles in the construction activities like misuse of resources, late payment for workers but all decision made have impacted the projects activities positively, once we continue to work hard ,all activities will end early"

\subsubsection{Relationship between decision making process and roads constructions projects implementation}

The third objective of study was to establish relationship between decisions making process and road construction projects implementation at zindiro-birembo-gasanze roads constructions project in Gasabo district. The participants were asked to show their views by answering the questionnaires in the space provided and the results were interpreted in the form of $\mathbf{S D}=$ Strongly Disagree, $\mathbf{D}=$ disagree, $\mathbf{N}=$ Neutral, $\mathbf{A}=$ Agree, $\mathbf{S A}=$ Strongly agree as Likert scale.

Researcher were interested to investigate the relationship of decision made in the zindiro-birembo-gasanze roads constructions project activities for its implementation and the results were summarized in the table 9 The findings were based on how decision making process relate to the roads construction projects implementation and the majority (95.0\%) of respondents were agreed that there is a relationship between decision making and construction activity in the company and 3.3\% of respondents were disagreed with the statement while $1.7 \%$ of respondents were refused to show their about the relationship of decision making process and roads constructions project implementation, with those findings, there is a very strong relationship decision making process and roads constructions project implementation.

The second statements were based to know if there is improvement on the projects works when new decision made, the majority (96.6\%) of respondents were accepted that there is improvement on the projects works when new decision made and $3.4 \%$ of respondents were disagreed with the statement so there is improvement on the projects works when new decision made.The researcher were also interested to know if there is staff commitment during the implementation of roads construction projects implementation so the results were that majority (65.9\%)of respondents were agreed that there is staff commitment during the implementation of construction projects implementation and $21.8 \%$ of respondents were disagreed with the statements while $12.2 \%$ of respondents were neutral to the ideas.

Table 4. 2 Relationship of decision making and constructions projects implementation

\begin{tabular}{|c|c|c|c|c|c|c|c|c|c|c|}
\hline & SD & & D & & $\mathbf{N}$ & & $\mathbf{A}$ & & SA & \\
\hline Statements & $\mathbf{F r}$ & $\%$ & $\mathbf{F r}$ & $\%$ & $\mathbf{F r}$ & $\%$ & $\mathbf{F r}$ & $\%$ & $\mathbf{F r}$ & $\%$ \\
\hline $\begin{array}{l}\text { There is a relationship between decision making } \\
\text { and construction activity in the company }\end{array}$ & 2 & 0.8 & 6 & 2.5 & 4 & 1.7 & 73 & 30.7 & 153 & 64.3 \\
\hline $\begin{array}{l}\text { There is improvement on the projects works when } \\
\text { new decision made. }\end{array}$ & 2 & 0.8 & 6 & 2.5 & 0 & 0 & 0 & 0 & 230 & 96.6 \\
\hline $\begin{array}{l}\text { There is staff commitment during the } \\
\text { implementation of construction projects. }\end{array}$ & 21 & 8.8 & 31 & 13.0 & 29 & 12.2 & 125 & 52.5 & 32 & 13.4 \\
\hline
\end{tabular}


Decision making has direct positive impact on

project performance.

$\begin{array}{lllllllll}8 & 3.4 & 19 & 8.0 & 5 & 2.1 & 161 & 67.6 & 45\end{array}$

Decision making process facilitate the effectiveness of resources use in an organization.

$\begin{array}{llllllllll}7 & 2.9 & 7 & 2.9 & 7 & 2.9 & 142 & 59.7 & 75 & 31.5\end{array}$

Decision making guide for the success of the implantation of roads construction projects

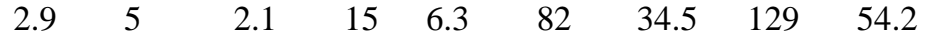

\section{Primary Data, 2021}

The results reveled in table 9 shown that decision making has direct positive impact on roads constructions project implementation, the majority $(86.5 \%$ )of respondents were agreed that decision making process has direct positive impact on roads constructions project implementation in Rwanda while the $11.4 \%$ of respondents were disagreed the statement and $2.1 \%$ of the respondents were refused to say anything about how decision making process has direct positive impact on roads constructions project implementation .The findings shown in table 4.8 indicate that decision making process facilitate the effectiveness of resources use in an organization, the majority $(91.2 \%)$ of respondents indicated that decision making process facilitate the effectiveness of resources use in an organization and $5.8 \%$ of respondents were disagreed with the statements while $2.9 \%$ of respondents were neutral on how the decision making process facilitate the effectiveness of resources use in an organization

\subsubsection{Correlation of variables}

The researcher wanted to know the correlation between the decision making process on the implementation of roads construction projects and the findings were shown in the table 10

Table 10 Correlation of variable

STATEMENT
Decision making process construction project

\begin{tabular}{llcc}
\hline Decision making & Pearson Correlation & 1 & $.955^{* *}$ \\
process & Sig. (2-tailed) & & .000 \\
& $\mathrm{~N}$ & 238 & 238 \\
Implementation of & Pearson Correlation & $.955^{* *}$ & 1 \\
roads construction & Sig. (2-tailed) & .000 & 238 \\
project & $\mathrm{N}$ & 238 & \\
\hline
\end{tabular}

\section{Implementation of roads}

**. Correlation is significant at the 0.01 level (2-tailed).

Findings in table 10 indicated that implementation of roads construction project and Decision making process were correlative with the success of reduction student's drop-out rate. The correlation coefficients are shown in table $4.9 \mathrm{r}=0.955$ is accordingly and was produced with p-value of 000 of a 2-tailed. The findings show strong positive and statistically significant and the Decision making process can be enhanced with the improved implementation of roads construction project significantly and the findings also are shown by the regression analysis of two variables indicated in table 11

Table 11.Regression analysis Model of two variables

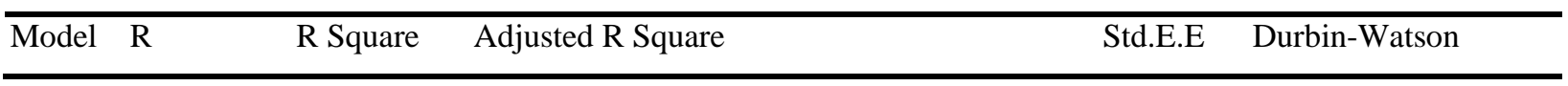

This publication is licensed under Creative Commons Attribution CC BY. 


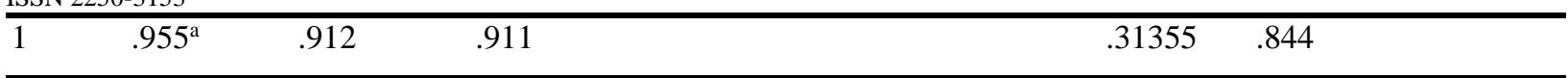

a. Predictors: (Constant), decision making process

b. Dependent Variable: implementation of roads construction project

The results revealed that the decision making process must be coherent with construction activities for early implementation of roads construction project as shown with the regression analysis $\mathrm{R}$ square of 0.912 indicating that decision making process are needed to implement and complete all activities of zindiro-birembo-gasanze roads constructions project in Gasabo district .

\section{CONCLUSION AND RECOMMANDATIONS}

\subsection{Conclusion}

This research expresses the whole perceptions of impact of decision making process on implementation of roads construction projects in Rwanda a case of zindiro-birembo-gasanze roads constructions project in Gasabo district and as conclusion , all respondents indicated that there is a need of different decisions to facilitate the implementation of roads constructions projects , research revealed that more decision making process facilitate the roads construction projects easily and faster and the third objective indicated strong positive correlation of the decision making and implementation of roads constructions therefore any organization should establish proper and decision making strategies to promote, enhance the projects ongoing and their implementation

\subsection{Recommendation}

The recommendation was made as follow:

This research advise the government to establish the policy on decision making strategies for public and private institution to ensure that there is successful and same decision making process used to promote the all projects accomplishments and implementation All construction companies must use various and clear decision making process and indicate how each decision made is used and respected to meets their projects success. The ministry of infrastructure should establish clear and proper measures to the use of resources management to enhance good service delivery in the construction area.It recommends that the policy makers to enhance the awareness of contractors' implementation strategies for successful delivery of construction projects success awareness of the community to involve in construction projects success. To respect the decision made to ensure projects proposed are completed and are done with the highest standard.

\section{REFERENCE}

Acharya, S. (2016). Analysis of Construction Delay Factor: A Korean Perspective." Proceedings of the $7^{\text {th }}$ Asia Pacific. Industrial Engineering and Management Systems Conference.

AfDB (2013). Rwanda Transport Sector Review and Action Plan. African Development Bank Group: Temporary Relocation Agency. 1002 Tunis - Belvédère. Retrieved from

Albanese, R.(2013). Team building: Improving Project Success. Austin: Construction IndustryInstitute .

Barkley et al. (2014). Customer-driven Project Management: A New Paradigm in Total Quality Implementation. New York: McGraw-Hill.

Belassi, W. (2016). A new framework for determining critical success/failure factors in projects. International Journal of Project Management,

Bell, S. (2014). Setting the stage for effective teams: Ameta-analysis of team design variables and teameffectiveness. Texas : A\&M University.

Beyerlein, M. (2016). Perceptions of project success: Center for the study of work teams. Texas, Denton.

This publication is licensed under Creative Commons Attribution CC BY.

http://dx.doi.org/10.29322/IJSRP.11.11.2021.p11912

WWW.ijsrp.org 
Bradley et al. (2017). The effect of personality type on team success. Journal of Management Developmen, 337-353.

Brundtland, G H. (2011). Report of the World Commission on Environment and Development - Our Common Future. New York: United Nations General Assembly.

Cannon-Bowers et al. (2012). Work teams in industry: A selected review and proposed frame. In R.W Swezeyand E. Salas (2011), Teams: Their training and performance. Ablex. Paper

Cannon-Bowers. (2012). A framework for developing project success measures in training, Theory research, and applications. Mahwah. care and business literature. Australian Health Review

Cohen et al. (2012). What makes teams work: Group effectiveness research from the shop floor to the executive suite. Journal of Management , 239-290.

Edmondson, A. C. (2019). Psychological safety and learning behavior in work teams. Admin.

Erdem, Ferda, Ozen and Janset. (2003). Cognitive and Affective Dimensions of Trust in Developing Team Performance. Team Performance Management: An International Journal, 9(5.6) 131-135.

Farrigaton, A. (2010). Decision making in Australia Middle Management: A Study to Investigate Attitude of Team Members, Team Member Effectiveness Perception and Team Environment. Sydney, Australia: University ofWestern Sydney.

Harris, P. (2006). Managing effectively through decision making. Team Success Management. New York:McGraw-Hill.

Hartenian, L.S. (2013), Team member acquisition of team knowledge, skills, and abilities.

Ingram, H. (2010). Linking decision making with performance. Journal of Team Performance

Jeeva, A. (2018). Supplier intelligence in MRO procurement. In Proceedings of 2018 IEEE International Conference on Service Operations and Logistics, and Informatics,

Johnson, P. (2010). The wolf pack: Team dynamics for the 21st century. Journal of Workplace Learning .

Jones, A., Richard, B., Paul, D., Sloane K., and Peter, F. (2017). Effectiveness of teambuilding in organization. Journal of Management.

Katzenbach \& Smith. (2013). The wisdom of teams: Creating the high-performance organization. Boston: Harvard Business School Press.

Kirk, S., Hills, B., and Baguly, C. (2013). Cost and Safety Efficient Design (CaSE) for rural highways in developing countries. International division, Transport Research Laboratory.

Lombard, P. (2012). Strategic Transport Master Plan for Rwanda. September 2012, Kigali, Rwanda.

Mantel , E. (2012). Factors Affecting Implementation of projects: A case study of Ministry of Roads. Jomo Kenyatta University of Agriculture and Technology, Department of Entrepreneurships and Procurement

Manz, C., and Neck, S. (2009). Team think: Beyond the group think syndrome in self-managing

Mathur, .D., and Kassa, H., (2013). Sustainable streets and highways stakeholders: Analysis of green roads rating systems.

Michael et al. (2011). Team Performance Assessmentand Measurement: Theory, Methods, and Applications (Applied Psychology). Mahwah, New Jersey: Lawrence Erlbaum Associates.

Miller, T. R. (May 2011). Constructing Sustainability: A Study of Emerging Scientific Research Trajectories. Phoenix: Arizona State University.

MININFRA. (2012). Public Transport Policy And Strategy For Rwanda. September 2012, Kigali, Rwanda.

Montgomery R., Howard S., Jr., and Hirsch A., (2015). Improving Environmental Sustainability In Road Projects. World Bank Group Report Number 93903-Lac.

REMA (2011). Building a Climate Resilient Infrastructure and Energy Sector for Rwanda. September 2011, Kigali, Rwanda. 
Nkurunziza.D \&Faraja.A.(2019).Sustainability and analysis of roads construction projects in Kigali.University of rwanda. Rwanda

Salas et al. (2007). Team performance and assessment measurement: Theory, methods and applications.

SHYIRAMBERE W. D.(2020).Technical and financial assessment of feeder road maintenance in Kigali city, Rwanda: Review University without Borders for the Open Society

Oladipo, J. (2008). Project Planning and Implementation at the Local Government Level: Lessons of Experience, European Journal of Social Sciences

Salas, E., Goodwin, G. F., and Burke, C. S. (2009). Team Effectiveness in Complex Organizations: Cross-Disciplinary Perspectives and Approaches. New York.Sci. Quart.

Scott et al. (2010). Support, Commitment, and Employee Outcomes in a Team Environment. Journal of Management.

Shah, K. (2011). Agenda 21 for Sustainable Construction in Developing Countries .The Indian Case.

World Bank. (2015). Roads: broadening the agenda, in Foster, V. and Briceño-Garmendia, C. (eds) Africa's Infrastructure: A Time for Transformation. Washington, DC: World Bank

Wageman, R. (2007). Critical success factors for creating superb self-managing teams. Organizational Dynamics.

Williams, M. (2012). The Principles of Team andDecision making Management. Collingwood: Sitepoint.work teams. Journal of Team Performance Management.

Yang et al. (2011). Research on construction project process success measurement. Industrial EngineeringandEngineering 